\title{
Comparison of Glufosinate-Based Herbicide Programs for Broad-Spectrum Weed Control in Glufosinate-Resistant Soybean
}

\author{
Jatinder S. Aulakh and Amit J. Jhala*
}

Because of the increasing number of glyphosate-resistant weeds, alternate herbicide-resistant crops and herbicides with different modes of action are required to protect crop yield. Glufosinate is a broad-spectrum POST herbicide for weed control in glufosinate-resistant crops, including soybean. The objective of this study was to compare herbicide programs with glufosinate applied singly at latePOST (LPOST) or sequentially at early POST (EPOST) followed by (fb) LPOST applications and PRE herbicides $\mathrm{fb}$ EPOST/LPOST glufosinate alone or tank-mixed with acetochlor, pyroxasulfone, or $S$-metolachlor in glufosinate-resistant soybean. A field experiment was conducted at the South Central Agriculture Laboratory in Clay Center, NE, in 2012 and 2013. Glufosinate applied in a single LPOST or sequential EPOST fb LPOST application controlled common lambsquarters, common waterhemp, eastern black nightshade, green foxtail, large crabgrass, and velvetleaf $\leq 82 \%$ and resulted in a weed density of 6 to 10 plants $\mathrm{m}^{-2}$ by the end of the season. Flumioxazin-, saflufenacil-, or sulfentrazone-based premixes provided 84 to $99 \%$ control of broadleaf and grass weeds tested in this study at $15 \mathrm{~d}$ after PRE application and a subsequent LPOST application of glufosinate alone controlled broadleaf and grass weeds 69 to $93 \%$ at harvest, depending on the herbicide program and weed species being investigated. The PRE application of sulfentrazone plus metribuzin fb EPOST glufosinate tank-mixed with acetochlor, pyroxasulfone, or $S$-metolachlor controlled the tested broadleaf and grass weeds $\geq 90 \%$, reduced density to $\leq 2$ plants $\mathrm{m}^{-2}$, and reduced weed biomass to $\leq 10 \mathrm{~g} \mathrm{~m}^{-2}$ and produced soybean yields of $\geq 4,450$ and $3,040 \mathrm{~kg} \mathrm{ha}^{-1}$ in 2012 and 2013, respectively. Soybean injury was 0 to 20\% from PRE or POST herbicides, or both and was inconsistent, but transient, during the 2-yr study, and it did not affect soybean yield. Sulfentrazone plus metribuzin applied PRE fb glufosinate EPOST tank-mixed with acetochlor, pyroxasulfone, or $S$-metolachlor provided the highest level of weed control throughout the growing season and increased soybean yield compared with a single LPOST or a sequential EPOST fb LPOST glufosinate application. Additionally, these herbicide programs provide four distinct mechanisms of action that constitute an effective weed-resistance management strategy in glufosinateresistant soybean.

Nomenclature: Acetochlor; flumioxazin; glufosinate; metribuzin; pyroxasulfone; saflufenacil; $S$ metolachlor; sulfentrazone; common lambsquarters, Chenopodium album L.; common waterhemp, Amaranthus rudis Sauer.; eastern black nightshade, Solanum ptychanthum Dunal; green foxtail, Setaria viridis (L.) Beauv.; large crabgrass, Digitaria sanguinalis (L.) Scop.; velvetleaf, Abutilon theophrasti Medik.; soybean, Glycine max (L.) Merr.

Key words: Broadleaf weeds, grass weeds, herbicide-resistance, resistance management, weed biomass.

\footnotetext{
Debido al creciente número de malezas resistentes a glyphosate, es necesario alternar cultivos resistente a herbicidas con diferentes modos de acción para proteger los rendimientos de los cultivos. Glufosinate es un herbicida POST de amplio espectro para el control de malezas en cultivos resistentes a glufosinate, incluyendo soja. El objetivo de este estudio fue comparar programas de herbicidas con glufosinate aplicado solo en POST-tarde (LPOST), o secuencialmente en POSTtemprano (EPOST) seguido de (fb) aplicaciones LPOST, y herbicidas PRE fb glufosinate solo en EPOST/LPOST, o mezclas en tanque con acetochlor, pyroxasulfone, o $S$-metolachlor, en soja resistente a glufosinate. Se realizó un experimento de campo en el Laboratorio de Agricultura del Centro Sur, en Clay Center, Nebraska, en 2012 y 2013. Glufosinate aplicado solo LPOST o en secuencia EPOST fb LPOST controló Chenopodium album, Amaranthus rudis, Solanum ptychanthum, Setaria viridis, Digitaria sanguinalis, y Abutilon theophrasti $\leq 82 \%$ y resultaron en una densidad de malezas de 6 a 10 plantas $\mathrm{m}^{-2}$ al final de la temporada. Premezclas basadas en flumioxazin, saflufenacil, o sulfentrazone
}

\footnotetext{
DOI: 10.1614/WT-D-15-00014.1

*Postdoctoral Scientist and Assistant Professor, Department of Agronomy and Horticulture, University of Nebraska-Lincoln, Lincoln, NE 68583. Corresponding author’s E-mail:Amit.Jhala@unl.edu
} 


\begin{abstract}
brindaron 84 a 99\% de control de malezas de hoja ancha y gramíneas evaluadas en este estudio a 15 d después de la aplicación; PRE fb glufosinate solo (EPOST/LPOST) controlaron malezas de hoja ancha y gramíneas 69 a $93 \%$ al momento de la cosecha, dependiendo del programa de herbicidas y las especies de malezas investigadas. La aplicación PRE de sulfentrazone más metribuzin fb EPOST con glufosinate mezclado en tanque con acetochlor, pyroxasulfone, o $S$ metolachlor controló las especies de malezas de hoja ancha y gramíneas evaluadas $\geq 90 \%$, redujo la densidad $\leq 2$ plantas $\mathrm{m}^{-2}$, redujo la biomasa de malezas $\leq 10 \mathrm{~g} \mathrm{~m}^{-2}$, y produjo rendimientos de soja $\geq 4,450$ y $3,040 \mathrm{~kg} \mathrm{ha}^{-1}$, en 2012 y 2013 , respectivamente. El daño en la soja fue 0 a $20 \%$ en los tratamientos PRE, POST, o ambos, y fue inconsistente pero fue transitorio, durante los 2 años del estudio, y no afectó el rendimiento de la soja. Sulfentrazone más metribuzin aplicados PRE fb glufosinate EPOST mezclado en tanque con acetochlor, pyroxasulfone, o $S$-metolachlor brindó el mayor nivel de control de malezas a lo largo de la temporada de crecimiento e incrementó el rendimiento de la soja al compararse con una aplicación de glufosinate LPOST o aplicaciones secuenciales EPOST fb EPOST. Adicionalmente, estos programas de herbicidas permitieron el uso de cuatro mecanismos de acción distintos lo que constituye una estrategia efectiva para el manejo de resistencia en soja resistente a glufosinate.
\end{abstract}

Glyphosate-resistant crop production systems were highly successful in achieving higher levels of weed control, facilitating the adoption of conservation tillage systems, and reducing the use of herbicides with groundwater advisories (Culpepper et al. 2000; Fernandez-Cornejo and Caswell 2006; Price et al. 2011; Young 2006). However, overreliance on glyphosate for weed control for several years has resulted in the evolution of glyphosateresistant weeds (Culpepper et al. 2006; Owen and Zelaya 2005; VanGessel 2001). As of 2015, 31 weed species worldwide have evolved resistance to glyphosate, including 14 species in the United States (Heap 2015). In Nebraska, glyphosateresistance has been confirmed in common ragweed (Ambrosia artemisiifolia L.), common waterhemp, horseweed [Conyza canadensis (L.) Cronq.], giant ragweed (Ambrosia trifida L.), kochia [Kochia scoparia (L.) Schrad.], and Palmer amaranth (Amaranthus palmeri S. Wats.) (Jhala 2015).

Control of glyphosate-resistant weeds is a challenge, particularly for soybean growers, because effective POST herbicides are limited (Riley and Bradley 2014). In addition, several glyphosateresistant weeds, including common waterhemp, are also resistant to acetolactate synthase (ALS)-inhibiting herbicides (Heap 2015; Sarangi et al. 2015). Therefore, alternate herbicide-resistant crops or diversified herbicide programs are required to manage multiple herbicide-resistant weeds. Recently, weed management has shifted toward glufosinate (Liberty Link, Bayer CropScience, Alfred-Nobel-Str. 50, D-40789, Monheim am Rhein, Germany)-based systems in the midsouthern United States, especially in areas with glyphosate-resistant Palmer amaranth infestations (Riar et al. 2013). Glufosinate-resistant soybean was developed by incorporating the $P A T$ gene of Streptomyces viridochromogenes (Droge et al. 1992), which encodes for phosphinothricin $N$ acetyltransferase (EC 2.3.1.183), an enzyme that renders glufosinate nonphytotoxic (Devine et al. 1993). Glufosinate-resistant soybean was first released for large-scale commercial cultivation in 2009, although limited cultivation had already begun in 1999 (Wiesbrook et al. 2001).

Glufosinate is a nonselective, contact, broadspectrum, POST herbicide (Haas and Muller 1987). It inhibits the glutamine synthetase enzyme (EC 6.3.12) and thereby causes rapid accumulation of ammonia and glyoxylate within the plant, eventually leading to cell membrane disruption and necrosis (Devine et al. 1993; Hinchee et al. 1993). Glufosinate efficacy has been variable for control of grass weeds, and it has no soil-residual activity (Ritter and Menbere 2001; Steckel et al. 1997; Thomas et al. 2007). Poor control of giant foxtail (Setaria faberi Herrm.) with early POST application of glufosinate in glufosinate-resistant soybean has been reported (Ritter and Menbere 2001). Furthermore, glufosinate efficacy is dependent on the growth stage of the weed. For example, Steckel et al. (1997) reported 45\% less control of giant foxtail, common lambsquarters, common cocklebur (Xanthium strumarium L.), and Pennsylvania smartweed (Polygonum pensylvanicum L.) when glufosinate was applied at $420 \mathrm{~g} \mathrm{ha}^{-1}$ to $15-$ $\mathrm{cm}$-tall, compared with 10-cm-tall, plants. Weedstage specificity, limited grass activity, and lack of soil residual activity of glufosinate necessitate sequential applications or tank-mixing with residual herbicides such as acetochlor or $S$-metolachlor to enhance the degree and duration of weed control in glufosinate-resistant corn (Zea mays L.), cotton (Gossypium hirsutum L.), and soybean (Aulakh 
2013; Aulakh et al. 2012, 2013; Beyers et al. 2002; Lanie et al. 1994). Preplant or PRE residual herbicides with multiple modes of action can reduce the number of POST glufosinate applications (Bruce and Kells 1990; Bruff and Shaw 1992a,b; Riley et al. 2014). For example, Lanie et al. (1994) reported 98\% control of pitted morningglory (Ipomoea lacunosa L.) with a tank-mixture of glufosinate and imazaquin, which was $36 \%$ greater than when glufosinate was applied alone in glufosinate-resistant soybean.

Several ALS-inhibiting, soil-applied herbicides, such as chlorimuron, cloransulam, flumetsulam, imazaquin, and imazethapyr have been widely used in soybean, particularly before the commercialization of glyphosate-resistant soybean (Dayan et al. 1996; Dirks et al. 2000; Duff et al. 2008; Ellis and Griffin 2002; Whitaker et al. 2010). However, because of their repeated usage, 151 weed species have been confirmed resistant to ALS-inhibitors by 2014 (Heap 2015). Therefore, residual herbicides, such as acetochlor, flumioxazin, fomesafen, metribuzin, pendimethalin, or sulfentrazone applied PRE, as well as POST herbicides, such as acifluorfen, fomesafen, or lactofen, are being used for managing ALS and glyphosate-resistant weeds in soybean (Riley and Bradley 2014; Sarangi et al. 2015). Additionally, several herbicides, including acetochlor, cloransulam, dimethenamid- $P$, and $S$ metolachlor have been registered for POST application in soybean. When applied POST, residual herbicides are usually tank-mixed with foliar-active herbicides, such as glyphosate, in glyphosateresistant crops or with glufosinate in glufosinateresistant crops (Aulakh et al. 2012, 2013, TaylorLovell et al. 2002; Thomas et al. 2007; Whitaker et al. 2010). Additionally, pyroxasulfone (an herbicide that inhibits very long chain fatty acid synthesis) is registered for weed control in several crops, including soybean. It can be applied PRE or POST from the first- to third-trifoliate leaf stage in soybean (Anonymous 2015). Although the PRE herbicides provide early season weed control and allow for flexibility in timing of POST applications, tank-mixing residual herbicides with POST herbicides may extend the residual weed control later into the season (Knezevic et al. 2009). To minimize selection pressure and improve grass-weed control, glufosinate can be applied in conjunction with residual herbicides applied PRE or POST in glufosinate-resistant soybean weed-management systems.

The objectives of this study were to (1) compare broadleaf and grass weed control across different glufosinate-based herbicide programs with and without residual herbicides, and (2) evaluate their effect on soybean injury and yield. We hypothesized that broadleaf and grassy weeds would be more effectively controlled with (1) sequential glufosinate applications than single application, (2) a residual PRE herbicide followed by (fb) glufosinate applied alone or tank-mixed with a residual herbicide compared with a sequential glufosinate program, and (3) a residual PRE herbicide $\mathrm{fb}$ glufosinate tank-mixed with a residual herbicide compared with a residual PRE fb glufosinate program.

\section{Materials and Methods}

The field experiment was conducted at South Central Agricultural Laboratory, University of Nebraska-Lincoln, Clay Center, NE $\left(40.58^{\circ} \mathrm{N}\right.$, $\left.98.14^{\circ} \mathrm{W}\right)$ in 2012 and 2013. Soil was a Crete silt loam (fine, montmorillonitic, mesic, Pachic Argiustolls) with a $\mathrm{pH}$ of $6.5,17 \%$ sand, $58 \%$ silt, $25 \%$ clay, and $2.5 \%$ organic matter. The previous crop was glyphosate-resistant corn, planted under conventional tillage with EPOST and LPOST applications of glyphosate applied at $950 \mathrm{~g} \mathrm{ha}^{-1}$. The experiment was arranged in a randomized completeblock design with four replications. The site was tilled before soybean was planted, and fertilizers were applied per local recommendations. Glufosinate-resistant soybean ('Stine S100211') was planted at 370,000 seeds ha ${ }^{-1}$ on May 7, 2012, and May 15,2013 . Seeds were planted $3 \mathrm{~cm}$ deep, with 76$\mathrm{cm}$ spacing between rows. The plot size was $3 \mathrm{~m}$ wide by $9 \mathrm{~m}$ long, comprising four soybean rows. The indigenous weed species present at the test site included common lambsquarters, common waterhemp, eastern black nightshade, green foxtail, large crabgrass, and velvetleaf. Twelve glufosinate-based herbicide programs, with and without residual herbicides, were compared for weed control and crop tolerance in glufosinate-resistant soybean (Table 1). A nontreated control was included for comparison. The herbicide application rates were selected based on the labeled rates in soybean.

Herbicides were applied with a $\mathrm{CO}_{2}$-pressurized backpack sprayer calibrated to deliver $140 \mathrm{~L} \mathrm{ha}^{-1}$ at 
Table 1. Herbicide treatments, application timing, rates, and the products used in glufosinate-resistant soybean in field experiments conducted at Clay Center, NE, in 2012 and 2013.

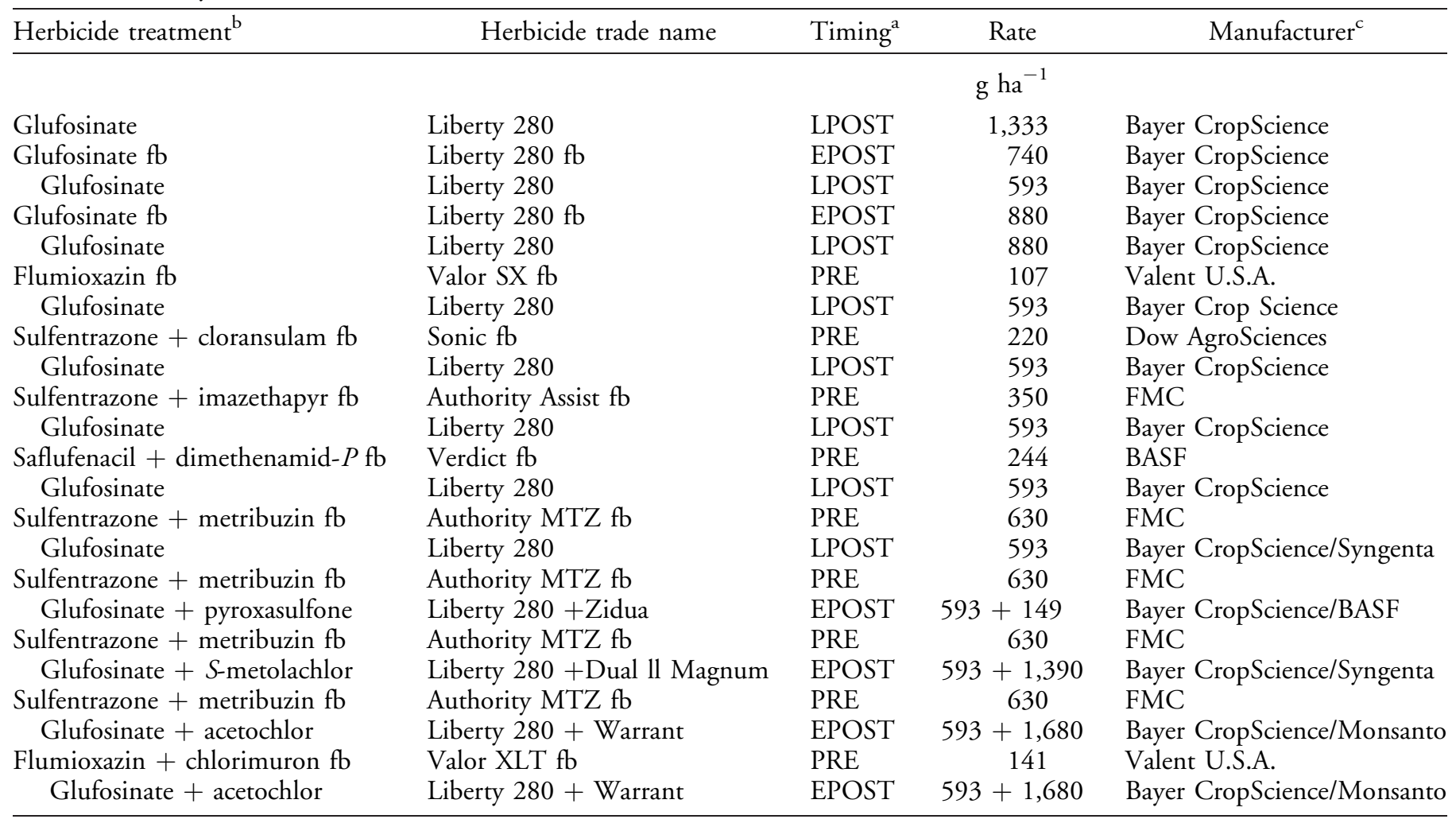

${ }^{a}$ Abbreviations: LPOST, late-POST; fb, followed by; EPOST, early POST.

b AMS, ammonium sulfate (DSM Chemicals North America, Augusta, GA 20901) was added at 2\% w/v to all EPOST and LPOST herbicide treatments.

c Bayer CropScience, Research Triangle Park, NC 27709; Valent U.S.A. Corporation, Walnut Creek, CA 94596; Dow AgroSciences, Indianapolis, IN 46268; FMC Corporation, Philadelphia, PA 19103; BASF Corporation, Research Triangle Park, NC 27709; Syngenta Crop Protection, Greensboro, NC 27419; Monsanto Company, St. Louis, MO 63167.

$276 \mathrm{kPa}$ and equipped with a four-nozzle boom fitted with AIXR 110015 flat-fan nozzles (TeeJet, Spraying Systems Co., P.O. Box 7900, Wheaton, IL 60189). Herbicide treatments were applied as PRE (May 8, 2012, and May 17, 2013), EPOST (May $28,2012$, and June 6,2013$)$ to V2 soybean, and LPOST (June 21, 2012, and July 2, 2013) to V6 soybean. Glufosinate was applied in sequential EPOST and LPOST applications, which is a standard growers' practice in glufosinate-resistant soybean. When the PRE herbicides were followed by LPOST glufosinate-alone, the objective was to evaluate residual activity of PRE herbicide and control of late season weeds. When PRE herbicides were followed by EPOST glufosinate tank-mixed with residual herbicides (acetochlor, pyroxasulfone, or $S$-metolachlor), the objective was to evaluate overlapping residual programs and to avoid weed escapes. The experimental site was under a central pivot-irrigation system; the crop was irrigated within a week of residual herbicide application and as required to prevent drought stress during the growing season.

Visual weed-control data were collected on a scale of 0 to $100 \%$ ( $0 \%$ equaling no control and $100 \%$ equaling complete control) at $15 \mathrm{~d}$ after PRE (DAPRE) and early-POST treatments, 15 and $30 \mathrm{~d}$ after late-POST herbicide treatment, and within a week before soybean harvest. Herbicide injury symptoms on soybean were recorded on a scale of 0 to $100 \%$ (0\% equaling no injury and $100 \%$ equaling plant death) at the same time as weed control. Weed densities were assessed from two randomly placed $0.25-\mathrm{m}^{2}$ quadrats per plot at 15 DAPRE and $30 \mathrm{~d}$ after late-POST herbicide treatments, and within a week before soybean harvest. Weeds were clipped at the stem base within $2 \mathrm{~cm}$ from the soil surface, dried in an oven for $72 \mathrm{~h}$ 
at $65 \mathrm{C}$, and the biomass was recorded. Soybean was harvested using a plot combine, and yields were adjusted to $13 \%$ moisture content.

Statistical Analysis. Data were subjected to ANOVA using the PROC GLIMMIX in SAS version 9.3 (SAS Institute Inc, 100 SAS Campus Dr., Cary, NC 27513). Herbicide treatments and experimental year were the fixed effects, whereas replication was considered a random effect in the model. To satisfy ANOVA assumptions, visual weed-control estimates, weed density, and biomass data were arcsine square-root transformed before analysis. However, back-transformed data are presented with mean separation based on transformed data. If the year-by-treatment interaction was not significant, data were combined. Where the ANOVA test indicated treatment effects were significant, means were separated at $\mathrm{P} \leq 0.05$ using Fisher's protected LSD test.

\section{Results and Discussion}

Year-by-treatment interaction was not significant for all response variables, with the exception of soybean injury and yield. Therefore, data were pooled over years, but soybean injury and seed yield data are presented separately by year. Early spring was comparatively drier in 2013 than in 2012, which may have resulted in differences in soybean injury rates. Year-by-treatment interaction for soybean yield was significant $(\mathrm{P}<0.0001)$ because of hail damage in 2013 that significantly reduced yield.

The most common broadleaf weeds infesting the experimental site in both years were common lambsquarters, common waterhemp, eastern black nightshade, and velvetleaf. Glufosinate $(1,333 \mathrm{~g}$ $\mathrm{ha}^{-1}$ ) applied in a single LPOST application controlled common lambsquarters, common waterhemp, and velvetleaf $\leq 65 \%$ at harvest compared with a maximum of $85 \%$ control from EPOST $\mathrm{fb}$ LPOST sequential applications of glufosinate at low $\left(740 \mathrm{fb} 593 \mathrm{~g} \mathrm{ha}^{-1}\right)$ or high $\left(880 \mathrm{fb} 880 \mathrm{~g} \mathrm{ha}^{-1}\right.$ ) rates (Table 2). However, a single LPOST glufosinate application was not different from sequential EPOST fb LPOST glufosinate applications at lower rates. Wiesbrook et al. (2001) observed 5 to 50\% greater control of common cocklebur, common lambsquarters, giant ragweed, and velvetleaf with sequential EPOST fb LPOST glufosinate applica- tions compared with a single EPOST application. Flumioxazin, saflufenacil plus dimethenamid- $P$, or sulfentrazone plus cloransulam/imazethapyr/metribuzin applied PRE controlled broadleaf weeds $>90 \%$ at 15 DAPRE. Krausz and Young (2003) reported $\geq 95 \%$ control of several broadleaf weeds, including common waterhemp, with sulfentrazone plus cloransulam applied PRE. The PRE application of flumioxazin, saflufenacil plus dimethenamid- $P$, or sulfentrazone plus metribuzin $\mathrm{fb}$ EPOST/ LPOST glufosinate controlled broadleaf weeds 69 to $87 \%$ at harvest. When sulfentrazone plus metribuzin applied PRE was fb EPOST glufosinate tank-mixed with acetochlor, pyroxasulfone, or $S$ metolachlor, broadleaf weeds were controlled $\geq 90 \%$. Residual activity of acetochlor and pyroxasulfone has been shown to provide $\geq 75 \%$ control of common waterhemp (Hausman et al. 2013). Taylor-Lovell et al. (2002) reported $\geq 90 \%$ control of common lambsquarters and velvetleaf with flumioxazin applied PRE fb POST glyphosate/ imazamox/imazethapyr compared with the same herbicides applied POST without flumioxazin in glyphosate-resistant soybean. Gonzini et al. (1999) reported 95\% weed control with PRE fb POST and POST tank-mixed herbicide programs compared with glyphosate-only program in glyphosate-resistant soybean.

Large crabgrass and green foxtail were the most common grass weeds in both years. Glufosinate applied in a single LPOST application controlled both grass weeds $\leq 67 \%$, compared with sequential EPOST fb LPOST glufosinate applications (82 to $87 \%$ ) at harvest (Table 3). Previous researchers reported consistently greater control $(>90 \%)$ of green foxtail (Chahal and Jhala 2015) and giant foxtail (Wiesbrook et al. 2001) with sequential EPOST fb LPOST glufosinate applications, compared with a single EPOST glufosinate application. Flumioxazin-, saflufenacil-, or sulfentrazone-based premixes controlled grass weeds $\geq 84 \%$ at 15 DAPRE. Chahal et al. (2014) reported $>70 \%$ control of volunteer corn with sulfentrazone plus imazethapyr/metribuzin applied PRE at $21 \mathrm{~d}$ after treatment (DAT). With the PRE application of sulfentrazone plus metribuzin $\mathrm{fb}$ EPOST application of glufosinate tank-mixed with acetochlor, pyroxasulfone, or $S$-metolachlor, control of large crabgrass and green foxtail was $\geq 94 \%$ at harvest, indicating season-long grass-weed control with these 


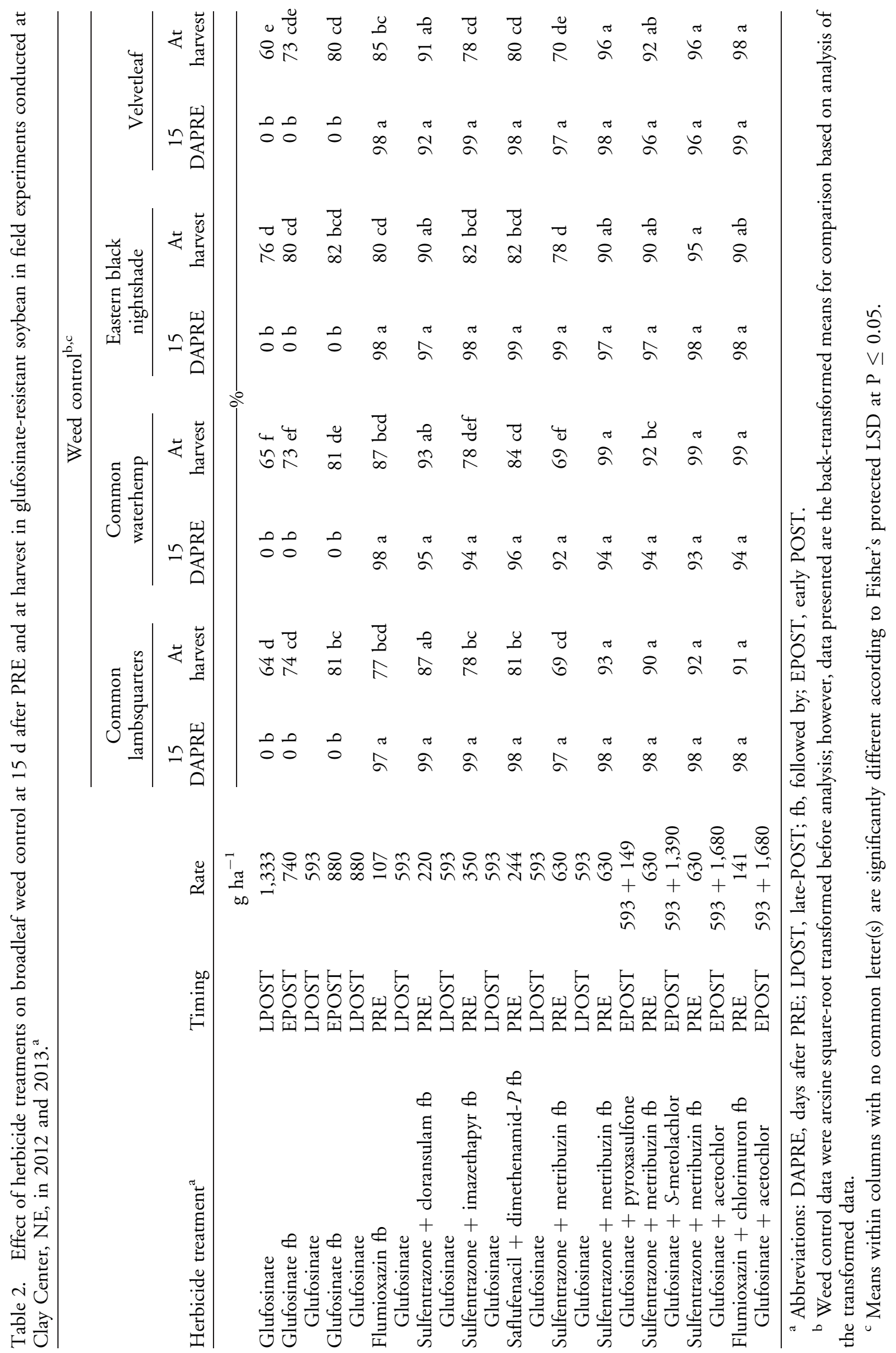

424 - Weed Technology 29, July-September 2015 


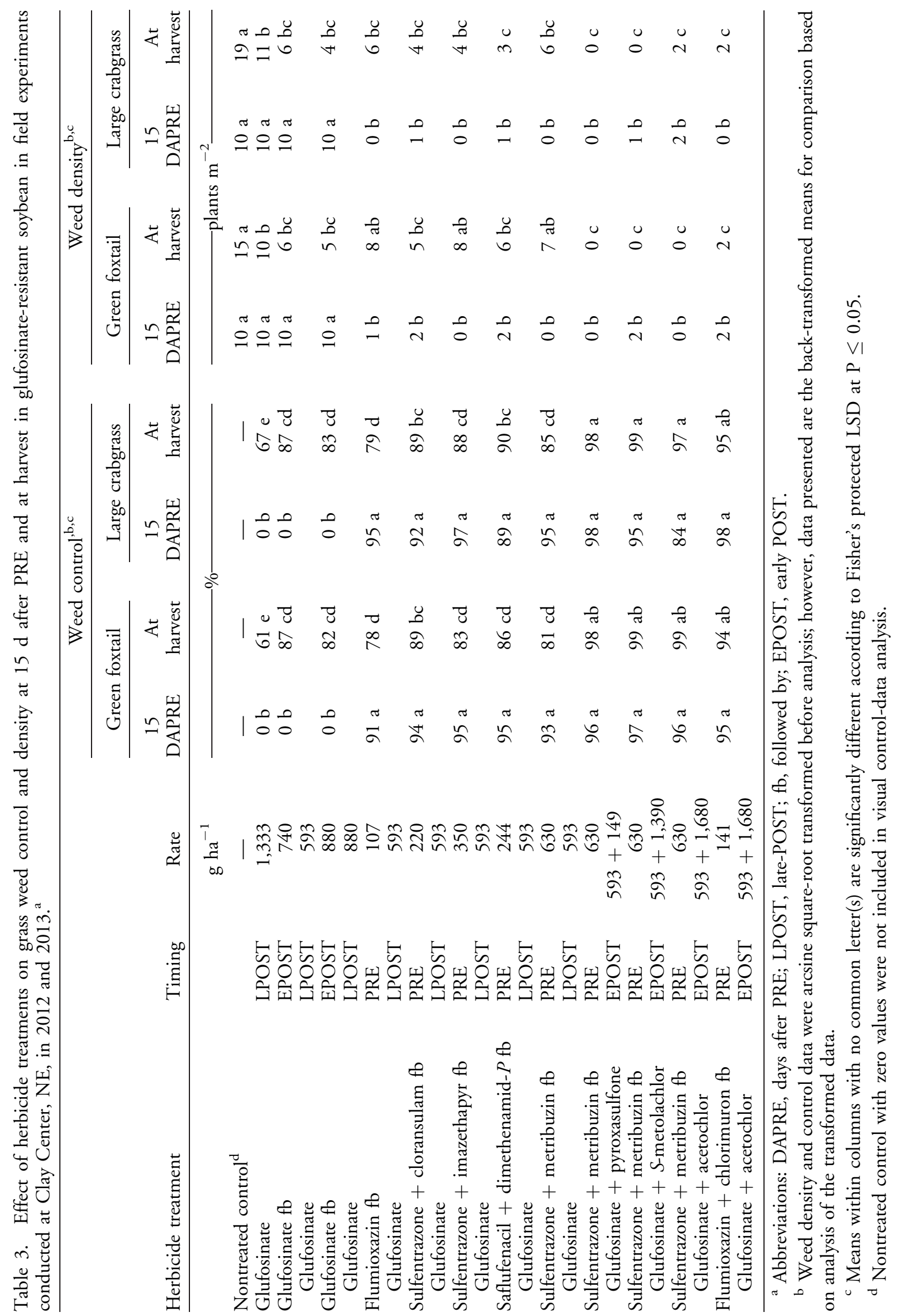


herbicide programs. Previous studies have reported $>85 \%$ control of green foxtail and large crabgrass with pyroxasulfone applied PRE (Geier et al. 2009; Knezevic et al. 2009).

Glufosinate applied in single LPOST or sequential EPOST $\mathrm{fb}$ LPOST application reduced broadleaf and grass-weed density to 6 to 12 and 4 to 11 plants $\mathrm{m}^{-2}$, respectively (Tables 3 and 4). Herbicides applied PRE reduced broadleaf and grass-weed density to as low as $\leq 2$ plants $\mathrm{m}^{-2}$ at 15 DAPRE. Although comparable with the residual herbicides applied PRE $\mathrm{fb}$ EPOST/LPOST glufosinate treatments, tank-mixing residual herbicides with EPOST glufosinate resulted in $\leq 4$ and $\leq 2$ plants $\mathrm{m}^{-2}$, broadleaf and grass weeds, respectively, at harvest. Similar results were reflected in weed biomass. Herbicide programs containing a PRE fb EPOST/LPOST glufosinate alone or tank-mixed with a residual herbicide usually resulted in the lowest weed biomass $\left(\leq 340 \mathrm{~g} \mathrm{~m}^{-2}\right)$ compared with a single LPOST or a sequential EPOST fb LPOST glufosinate application $\left(>360 \mathrm{~g} \mathrm{~m}^{-2}\right.$ ), indicating the importance of including residual herbicides in PRE or POST herbicide programs.

During both years, soybean injury was $<20 \%$ in response to any PRE treatment at 15 DAT (data not shown). Maximum injury (20\%) occurred with flumioxazin or flumioxazin plus chlorimuron applied PRE (15\%) (data not shown). Mahoney et al. (2014) reported similar levels of soybean response with flumioxazin. Year-by-treatment interaction was significant $(\mathrm{P}<0.0001)$ for POST herbicide injury evaluated at 15 DAT. In 2012, soybean injury was 15 to $20 \%$ when glufosinate was tank-mixed with acetochlor, pyroxasulfone, or $S$-metolachlor (Table 5). Culpepper et al. (2000) reported up to $34 \%$ injury with glufosinate in glufosinate-resistant soybean. In 2013, soybean injury ranged from 10 to $20 \%$ across POST herbicide programs; however, injury during both years was transient and did not affect soybean yield (Table 5). Similarly, Beyers et al. (2002) observed no yield penalty from injury with glufosinate applied alone or tank-mixed with other herbicides.

Year-by-treatment interaction for soybean yield was significant $(\mathrm{P}<0.0001)$ because of hail damage in 2013, which significantly reduced yield. In 2012 , soybean yield $\left(3,530 \mathrm{~kg} \mathrm{ha}^{-1}\right)$ with a single LPOST glufosinate treatment was comparable to the nontreated control, indicating failure of this treatment to provide season-long weed control and to prevent soybean yield reductions. Culpepper et al. (2000) reported that sequential applications of glufosinate or a PRE fb POST glufosinate program was more effective than a single glufosinate application in glufosinate-resistant soybean. In 2012, herbicide programs containing a PRE fb EPOST/LPOST glufosinate alone or in tank mixes produced soybean yields in the range of 4,230 to $4,590 \mathrm{~kg} \mathrm{ha}^{-1}$. However, in 2013, a PRE fb EPOST glufosinate tank-mixed with residual herbicides produced a greater yield, compared with other treatments (Table 5). Results indicate the importance of a PRE residual herbicide to avoid early season weed competition. In fact, a PRE fb EPOST glufosinate tank-mixed with a residual herbicide provided season-long control of late-emerging weeds, such as common waterhemp, and thereby preserved soybean yield potential. Previous studies have shown that either PRE fb POST or sequential POST foliar programs are more likely to produce greater yields than a single POST program in glyphosate- or glufosinate-resistant soybean (Heatherly et al. 2002; Hoffner et al. 2012; Payne and Oliver 2000; Stewart et al. 2011).

Results indicate that glufosinate applied in a single LPOST application may not control the weed species tested in this study effectively enough to ensure optimum soybean yield. Sequential EPOST $\mathrm{fb}$ LPOST applications of glufosinate were more effective, but this practice may impose selection pressure, leading to the evolution of glufosinateresistant weeds. In fact, resistance to glufosinate has been confirmed in goosegrass [Eleusine indica (L.) Gaertn.] in Malaysia (Jalaludin et al. 2010) and in Italian ryegrass [Lolium perenne L. ssp. multiflorum (Lam.) Husnot] in Oregon (Avila-Garcia et al. 2012). Therefore, a herbicide program with sequential applications of glufosinate-only should be avoided. Herbicides applied PRE were highly effective in reducing early season broadleaf and grass-weed densities and allowed for flexibility in the application timing of the POST herbicides (Grichar 2006). Several studies reported that weed management programs consisting of a residual PRE herbicide $\mathrm{fb}$ a POST herbicide have the potential to reduce weed densities, improve weed control, and, in some instances, preserve yield potential (Aulakh et al. 2011, 2012; Barnes and Oliver 2004; Ellis and 


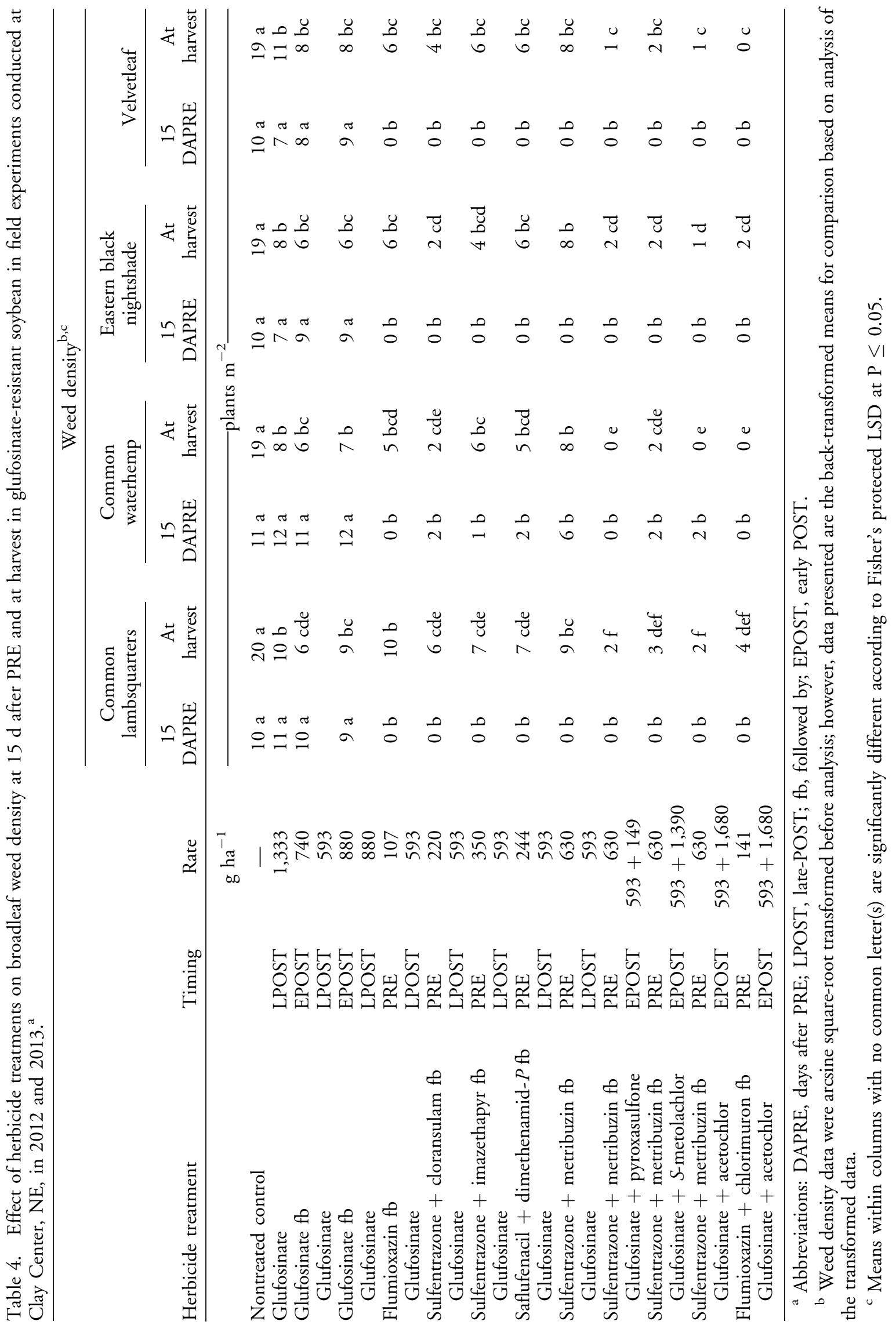

Aulakh and Jhala: Weed control in glufosinate-resistant soybean • 427 
Table 5. Effect of herbicide treatments on weed biomass, soybean injury, and yield in glufosinate-resistant soybean in field experiments conducted at Clay Center, NE, in 2012 and 2013. ${ }^{\mathrm{a}}$

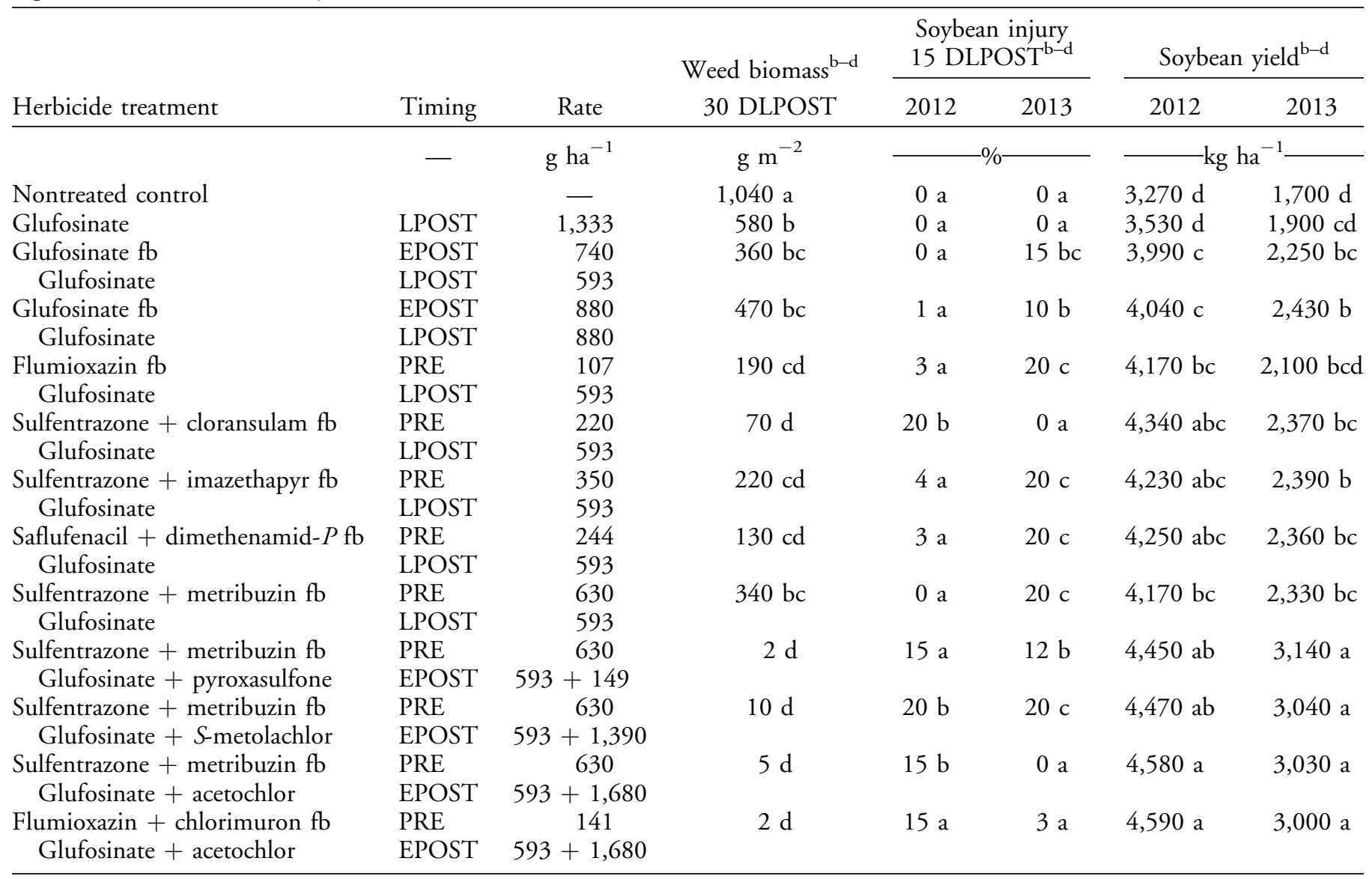

\footnotetext{
a Abbreviations: DLPOST, days after late-POST; LPOST, late-POST; fb, followed by; EPOST, early POST.

${ }^{\mathrm{b}}$ Weed biomass and soybean injury data were arcsine square-root transformed before analysis; however, data presented are the backtransformed means for comparison based on analysis of the transformed data.

${ }^{c}$ Means within columns with no common letter(s) are significantly different according to Fisher's protected LSD at P $\leq 0.05$.

${ }^{\mathrm{d}}$ Year-by-treatment interaction for weed biomass was not significant; therefore, data from both years were pooled; a significant difference was observed for soybean injury and yield between two years. Therefore, data are presented separately for 2012 and 2013.
}

Griffin 2002; Gardner et al. 2006; Norsworthy et al. 2012; Soltani et al. 2014).

Historically, weed control research in glufosinateresistant soybean has tested a few residual herbicides applied PRE or POST tank-mixed with glufosinate (Beyers et al. 2002; Culpepper et al. 2000; Norris et al. 2002). Additionally, many new prepackaged herbicide mixtures, such as sulfentrazone plus metribuzin, have recently been registered in soybean and limited literature exists on their efficacy on the weed species tested in this study. Results from this study showed that flumioxazin plus chlorimuron or sulfentrazone plus metribuzin applied PRE $\mathrm{fb}$ glufosinate EPOST tank-mixed with acetochlor, pyroxasulfone, or $S$-metolachlor may provide $\geq 88 \%$ control of tested weed species throughout the growing season and thereby preserve soybean yield. Inclusion of residual herbicides also offer other benefits, such as additional modes of action, which will reduce the selection pressure of a single herbicide (Diggle et al. 2003; Johnson et al. 2012), and reduction of the weed seed bank in the soil (Legleiter et al. 2009). Most important, current weed-resistance issues exclusively demand the adoption of integrated weed-management practices, including diversified herbicide programs.

\section{Literature Cited}

Anonymous (2015) Zidua ${ }^{\circledR}$ supplemental label. EPA Registration No. 7969-338. Research Triangle Park, NC: BASF. 12 p 
Aulakh JS, Price AJ, Balkcom KS (2011) Weed management and cotton yield under two row spacings in conventional and conservation tillage systems utilizing conventional, glufosinate-, and glyphosate-based weed management systems. Weed Technol 25:542-547

Aulakh JS, Price AJ, Enloe SF, van Santen E, Wehtje G, Patterson MG (2012) Integrated Palmer amaranth management in glufosinate-resistant cotton, I: soil-inversion, highresidue cover crops and herbicide regimes. Agronomy 2:295311

Aulakh JS (2013) Management of Palmer amaranth in glufosinate-resistant cotton and cogongrass eradication in the southern United States. Ph.D dissertation. Auburn, AL: Auburn University. $89 \mathrm{p}$

Aulakh JS, Price AJ, Enloe SF, Wehtje G, Patterson MG (2013a) Integrated Palmer amaranth management in glufosinateresistant cotton, II: primary, secondary and conservation tillage. Agronomy 3:28-42

Avila-Garcia WV, Sanchez-Olguin E, Hulting AG, MallorySmith C (2012) Target-site mutation associated with glufosinate resistance in Italian ryegrass (Lolium perenne L. ssp. multiflorum). Pest Manag Sci 68:1248-1254

Barnes JW, Oliver LR (2004) Preemergence weed control in soybean with cloransulam. Weed Technol 18:1077-1090

Beyers JT, Smeda R J, William GJ (2002) Weed management programs in glufosinate-resistant soybean (Glycine max). Weed Technol 16:267-273

Bruce JA, Kells JJ (1990) Horseweed (Conyza canadensis) control in no tillage soybeans (Glycine max) with preplant and preemergence herbicides. Weed Technol 4:642-647

Bruff SA, Shaw DR (1992a) Early season herbicide applications for weed control in stale seedbed soybeans (Glycine max). Weed Technol 6:36-44

Bruff SA, Shaw DR (1992b) Tank-mix combinations for weed control in stale seedbed soybeans (Glycine max). Weed Technol 6:45-51

Chahal PS, Jhala AJ (2015) Herbicide programs for control of glyphosate-resistant volunteer corn in glufosinate-resistant soybean. Weed Technol 19:431-443

Chahal PS, Kruger G, Blanco-Canqui H, Jhala AJ (2014) Efficacy of preemergence and postemergence soybean herbicides for control of glufosinate-, glyphosate-, and imidazolinone-resistant volunteer corn. J. Agric Sci 6:131-140

Culpepper AS, Grey TM, Vencill WK, Kichler JM, Webster TM, Brown SM, York AC, Davis JW, Hanna WW (2006) Glyphosate-resistant Palmer amaranth (Amaranthus palmeri) confirmed in Georgia. Weed Sci 54: 620-626

Culpepper AS, York AC, Batts RB, Jennings KM (2000) Weed management in glufosinate- and glyphosate-resistant soybean (Glycine max). Weed Technol 14:77-88

Dayan FE, Green HM, Weete JD, Hancock G (1996) Postemergence activity of sulfentrazone: effect of surfactants and leaf surfaces. Weed Sci 44:797-803

Devine MS, Duke O, Fedtke C (1993) Inhibition of amino acid biosynthesis. Pages 252-263 in Physiology of Herbicide Action. Englewood Cliffs, NJ: Prentice Hall.

Diggle AJ, Neve PB, Smith EP (2003) Herbicides used in combination can reduce the probability of herbicide resistance in finite weed populations. Weed Res 43:371-382
Dirks JT, Johnson WG, Smeda RJ, Wiebold WJ, Massey RE (2000) Use of preplant sulfentrazone in no-till, narrow-row, glyphosate-resistant Glycine max. Weed Sci 48:628-639

Dröge W, Broer I, Puhler A (1992) Transgenic plants containing the phosphinothricin- $N$-acetyl transferase gene metabolize the herbicide L-phosphinothricin (glufosinate) differently from untransformed plants. Planta 187:142-151

Duff MG, Al-Khatib K, Peterson DE (2008) Efficacy of preemergence application of $S$-metolachlor plus fomesafen or metribuzin as an element in the control of common waterhemp (Amaranthus rudis Sauer) in soybeans. Trans Kans Acad Sci 111:230-238

Ellis JM, Griffin JL (2002) Benefits of soil-applied herbicides in glyphosate-resistant soybean (Glycine max). Weed Technol 16:541-547

Fernandez-Cornejo J, Caswell M (2006) The first decade of genetically engineered crops in the United States [electronic report]. Econ Inf Bull 11, $36 \mathrm{p}$

Gardner AP, York AC, Jordan DL, Monks DW (2006) Management of annual grasses and Amaranthus spp. in glufosinate-resistant cotton. J Cotton Sci 10:328-338

Geier PW, Stahlman PW, Regehr DL, Olson BL (2009) Preemergence herbicide efficacy and phytotoxicity in grain sorghum. Weed Technol 23:197-201

Gonzini LC, Hart SE, Wax. LM (1999) Herbicide combinations for weed management in glyphosate-resistant soybean (Glycine max). Weed Technol 13:354-360

Grichar WJ (2006) Using soil-applied herbicides in glyphosateresistant soybeans along the Texas Gulf Coast. Weed Technol 20:633-639

Haas P, Muller F. 1987. Behaviour of glufosinate-ammonium in weeds. Pages 1075-1082 in Proceedings of the 10th BCPC Congress-Weeds. Alton, UK: British Crop Production Council

Hausman NE, Tranel PJ, Riechers DE, Maxwell DJ, Gonzini LC, Hager AG (2013) Responses of an HPPD inhibitorresistant waterhemp (Amaranthus tuberculatus) population to soil-residual herbicides. Weed Technol 27:704-711

Heap I (2015) The International Survey of Herbicide Resistant Weeds. http://www.weedscience.com. Accessed March 20, 2014

Heatherly LG, Elmore CD, Spurlock SR (2002) Weed management systems for conventional and glyphosate-resistant soybean with and without irrigation. Agron J 94:1419-1428

Hinchee MAW, Padgette SR, Kishore GM, Delannay X, Fraley RT (1993) Herbicide-tolerant crops. Pages 243-263 in Kung S, Wu R, eds. Transgenic Plants. San Diego, CA: Academic

Hoffner AE, Jordan DL, York AC, Dunphy EJ, Everman WJ (2012) Management of Palmer amaranth (Amaranthus palmeri) in glufosinate-resistant soybean (Glycine max) with sequential applications of herbicides. ISRN Agron 2012:131650. doi:10.5402/2012/131650

Jalaludin A, Ngim J, Bali BB, Zazali A (2010) Preliminary findings of potentially resistant goosegrass (Eleusine indica) to glufosinate-ammonium in Malaysia. Weed Biol Manag $10: 256-260$

Jhala AJ (2015) Herbicide-resistant weeds. Pages 18-19 in Knezevic SZ, Jhala AJ, Klein RN, Kruger GR, Reicher ZJ, Wilson RG, Shea PJ, Ogg CL, eds. 2015 Guide for Weed 
Management in Nebraska with Insecticide and Fungicide Information. Lincoln, NE: University of Nebraska-Lincoln Extension

Johnson G, Breitenbach F, Behnken L, Miller R, Hoverstad T, Gunsolus J (2012) Comparison of herbicide tactics to minimize species shifts and selection pressure in glyphosateresistant soybean. Weed Technol 26:189-194

Knezevic SZ, Datta A, Scott J, Klein RN, Golus J (2009) Problem weed control in glyphosate-resistant soybean with glyphosate tank mixes and soil-applied herbicides. Weed Technol 23:507-512

Krausz RF, Young BG (2003) Sulfentrazone enhances weed control of glyphosate in glyphosate-resistant soybean (Glycine max). Weed Technol 17:249-255

Lanie AJ, Griffin JL, Vidrine PR, Reynolds DB (1994) Herbicide combinations for soybean (Glycine max) planted in stale seedbed. Weed Technol 8:17-22

Legleiter TR, Bradley KW, Massey RE (2009) Glyphosateresistant waterhemp control and economic returns with herbicide treatments in soybean. Weed Technol 23:54-61

Mahoney KJ, Shropshire C, Sikkema PH (2014) Weed management in conventional- and no-till soybean using flumioxazin/pyroxasulfone. Weed Technol 28:298-306

Norris JL, Shaw DR, Snipes CE (2002) Influence of row spacing and residual herbicides on weed control in glufosinate-resistant soybean (Glycine max). Weed Technol 16: 319-325

Norsworthy JK, Ward SM, Shaw DR, Llewellyn RS, Nichols RL, Webster TM, Bradley KW, Frisvold G, Powles SB, Burgos NR, Witt WW, Barrett M (2012) Reducing the risks of herbicide resistance: best management practices and recommendations. Weed Sci 60:31-62

Owen MDK, Zelaya IA (2005) Herbicide-resistance crops and weed resistance to herbicides. Pest Manag Sci 61:301-311

Payne SA, Oliver LR (2000) Weed control programs in drilled glyphosate-resistant soybean. Weed Technol 14:413-422

Price AJ, Balkcom KS, Culpepper SA, Kelton JA, Nichols RL, Schomberg H (2011) Glyphosate-resistant Palmer amaranth: a threat to conservation tillage. J Soil Water Conserv 66:265275

Riar DS, Norsworthy JK, Steckel LE, Stephenson IV DE, Bond JA (2013) Consultant perspectives on weed management needs in midsouthern United States cotton: a follow-up survey. Weed Technol 27:778-787

Riley EB, Bradley KW (2014) Influence of application timing and glyphosate tank mix combinations on the survival of glyphosate-resistant giant ragweed (Ambrosia trifida) in soybean. Weed Technol 28:1-9
Riley EB, Raymond EM, Bradley KW (2014) Influence of herbicide programs on glyphosate-resistant giant ragweed (Ambrosia trifida L.) density, soybean yield, and net economic return in glyphosate- and glufosinate-resistant soybean. Crop Manag 13. DOI:10.2134/CM-2013-0015b-RS

Ritter RL, Menbere H (2001) Weed management systems utilizing glufosinate-resistant corn (Zea mays) and soybean (Glycine max). Weed Technol 15:89-94

Sarangi D, Sandell LD, Knezevic SZ, Aulakh JS, Lindquist JL, Irmak S, Jhala AJ (2015) Confirmation and control of glyphosate-resistant common waterhemp (Amaranthus rudis) in Nebraska. Weed Technol 29:82-92. doi/pdf/10.1614/WTD-14-00090.1

Soltani N, Nurse R, Sikkema P (2014) Two-pass weed management with preemergence and postemergence herbicides in glyphosate-resistant soybean. Agric Sci 5:504-512. doi: 10. 4236/as.2014.56052.

Steckel GJ, Wax LM, Simmons FW, Phillips II WH (1997) Glufosinate efficacy on annual weeds is influenced by rate and growth stage. Weed Technol 11:484-488

Stewart CL, Nurse RE, Ban Eerd LL, Vyn RJ, Sikkema PH (2011) Weed control, environmental impact, and economics of weed management strategies in glyphosate-resistant soybean. Weed Technol 25:535-541

Taylor-Lovell S, Wax LM, Bollero G (2002) Preemergence flumioxazin and pendimethalin and postemergence herbicide systems for soybean (Glycine max). Weed Technol 16:502-511

Thomas WE, Everman WJ, Allen J, Collins J, Wilcut JW (2007) Economic assessment of weed management systems in glufosinate-resistant, glyphosate-resistant, imidazolinone-tolerant, and nontransgenic corn. Weed Technol 21:191-198

VanGessel MJ (2001) Glyphosate-resistant horseweed from Delaware. Weed Sci. 49:703-705

Whitaker JR, York AC, Jordan DL, Culpepper AS (2010) Palmer amaranth (Amaranthus palmeri) control in soybean with glyphosate and conventional herbicide systems. Weed Technol 24:403-410

Wiesbrook ML, Johnson WG, Hart SE, Bradley PR, Wax LM (2001) Comparison of weed management systems in narrowrow, glyphosate- and glufosinate-resistant soybean (Glycine max). Weed Technol 15:122-128

Young BG (2006) Changes in herbicide use patterns and production practices resulting from glyphosate-resistant crops. Weed Technol 20:301-307

Received January 28, 2015, and approved April 2, 2015. 